\title{
Asupan makan DASH-like diet untuk mencegah risiko hipertensi pada wanita prediabetes
}

\author{
DASH-like diet intake to prevent hypertension risk in prediabetes women
}

Ayu Rahadiyanti ${ }^{1}$, Budi Yuli Setianto ${ }^{2}$, Martalena Br. Purba ${ }^{3}$

\begin{abstract}
Background: Prediabetics have cardiovascular risk factors such as obesity, hypertension, and dislipidemia. Unhealthy food intake can increase the risk of hypertension in prediabetes. Prediabetes hypertension has impact on increasing prevalence of diabetes and cardiovascular disease. Cohort study has showed that DASH diet is related with lower incidence of hypertension in women (1). Objective: Of this study had the purpose to know that inappropriate DASH like diet intake is associated with hypertension risk at prediabetes women in Puskesmas Tlogosari Kulon Semarang. Method: A cross sectional study was conducted in Puskesmas Tlogosari Kulon area on January - March 2014 among 117 prediabetes women. The subjects were selected using consecutive sampling. Independent variable in this study was DASH like diet intake which assessed from FFQ and the dependent variable was hypertension risk. The subject was classified as at risk for hypertension if in seated position, the mean of the two measurement was $\geq 120 / 80 \mathrm{mmHg}$. Chi-Square test and logistic regression were used to analyze the data. Results: The mean of DASH like diet score in subjects who were not at hypertension risk (3.31) was higher than subjects who were at hypertension risk (3.23). There were $90,77 \%$ person with hypertension risk who did not consume DASH like diet properly. But the association of DASH like diet intake with hypertension risk was not significant $(p=0.194)$. Multivariate result showed that there were association of family history ( $p=0.047)$, obesity $(p=0.016)$, and fat intake $(p=0.015)$ with hypertension risk. Conclusion: Inappropriate DASH like diet intake may increase the risk of hypertension, but it is not statistically significant.
\end{abstract}

KEY WORDS: DASH like diet, hypertension, women, prediabetes

\begin{abstract}
ABSTRAK
Latar belakang: Individu dengan prediabetes memiliki faktor risiko kardiovaskular seperti obesitas, hipertensi, dan dislipidemia. Asupan makan yang tidak sehat dapat meningkatkan risiko hipertensi pada prediabetes. Prediabetes dengan hipertensi mengakibatkan peningkatan prevalensi diabetes dan penyakit kardiovaskular. Studi kohort menunjukkan bahwa DASH diet berhubungan dengan rendahnya insiden hipertensi pada wanita (1). Tujuan: Membuktikan bahwa asupan makan yang tidak sesuai dengan DASH like diet berhubungan dengan risiko hipertensi pada wanita prediabetes di daerah Puskesmas Tlogosari Kulon Kota Semarang. Metode: Penelitian ini merupakan penelitian cross sectional dengan subjek 117 wanita prediabetes di daerah Puskesmas Tlogosari Kulon Kota Semarang. Pengambilan sampel dilakukan dengan menggunakan teknik consecutive sampling. Variabel independen adalah asupan makan DASH like diet yang diperoleh dengan metode FFQ dan variabel dependen adalah risiko hipertensi. Subjek penelitian berisiko hipertensi jika tekanan darah pada dua kali pengukuran dengan posisi duduk adalah $\geq 120 / 80 \mathrm{mmHg}$. Analisis data menggunakan uji Chi-Square dan regresi logistik. Hasil: Rerata skor asupan makan DASH like diet pada subjek penelitian yang tidak berisiko hipertensi $(3,31)$ lebih tinggi dibanding yang berisiko hipertensi $(3,23)$. Sebanyak $90,77 \%$ subjek penelitian berisiko hipertensi memiliki asupan makan yang tidak memenuhi DASH like diet. Namun, hasil uji bivariat menunjukkan hubungan yang tidak signifikan $(\mathrm{p}=0,194)$. Hasil uji multivariat terdapat hubungan antara riwayat penyakit keluarga $(\mathrm{p}=0,047)$; obesitas $(\mathrm{p}=0,016)$; dan asupan lemak $(\mathrm{p}=0,015)$ dengan risiko hipertensi. Simpulan: Asupan makan yang tidak sesuai DASH like diet dapat meningkatkan risiko hipertensi tetapi secara statistik tidak signifikan.
\end{abstract}

KATA KUNCI: DASH like diet, hipertensi, wanita, prediabetes

\section{PENDAHULUAN}

Penanda prediabetes yaitu kadar glukosa darah puasa 100-125 mg/dl dan atau kadar glukosa darah 2 jam post prandial 140-199 mg/dl. Dalam jangka waktu 3-5 tahun, 25\% prediabetes dapat berkembang menjadi diabetes mellitus tipe 2 (DMT2), 50\% tetap dalam kondisi prediabetes, dan $25 \%$ kembali pada kondisi glukosa darah normal (2). Pada tahun 2030, International Diabetes Federation (IDF) memprediksikan terdapat 398 juta penduduk dunia mengalami prediabetes (3). Hasil Riset

${ }^{1}$ Korespondensi: Minat Gizi dan Kesehatan, Program Studi S2 Ilmu Kesehatan Masyarakat Fakultas Kedokteran Universitas Gadjah Mada, Jl. Farmako, Sekip Utara Yogyakarta 55281,e-mail: rydi_90@yahoo.com

Bagian Kardiologi Rumah Sakit Umum Pusat Dr. Sardjito, Yogyakarta 55281 ${ }^{3}$ Instalasi Gizi Rumah Sakit Umum Pusat Dr. Sardjito, Yogyakarta 55281, e-mail: martalena_purba@yahoo.com 
Kesehatan Dasar (Riskesdas) tahun 2007 menunjukkan bahwa prevalensi DMT2 di daerah perkotaan di Indonesia adalah 5,7\% sedangkan prevalensi prediabetes hampir dua kali lipatnya yaitu 10,2\% (4). Jika diperkirakan prevalensi DMT2 akan meningkat, maka prevalensi prediabetes akan meningkat lebih tinggi karena menyerupai fenomena gunung es yaitu jumlah individu yang belum terdeteksi DMT2 (termasuk prediabetes) lebih banyak dibanding individu dengan DMT2. Lebih lanjut, hasil Riskesdas tahun 2007 menunjukkan bahwa prevalensi hipertensi pada prediabetes sebesar $15,1 \%$ sedangkan pada normotensi $8,4 \%$ (4). Pasien prediabetes dengan hipertensi memiliki risiko tinggi terjadi morbiditas dan mortalitas karena penyakit kardiovaskular dini (5). Oleh karena itu, kejadian hipertensi pada prediabetes perlu dicegah sehingga prevalensi penyakit kardiovaskular dapat ditekan.

Studi Dietary Approaches to Stop Hypertension (DASH) diet menunjukkan bahwa diet tinggi sayur, buah, dan hasil olahan susu rendah lemak yang kadar lemak jenuh dan lemak totalnya rendah serta tinggi kandungan kalium, kalsium, dan magnesium dapat menurunkan tekanan darah sistolik 6-11 $\mathrm{mmHg}$ dan tekanan darah diastolik 3-6 mmHg (6). Studi kohort menunjukkan bahwa pola makan DASH diet berhubungan dengan rendahnya insiden hipertensi pada wanita (1). Pada penelitian ini asupan makan menggunakan pedoman DASH diet, tetapi terdapat beberapa zat gizi yang anjuran konsumsinya menggunakan Angka Kecukupan Gizi (AKG) untuk populasi Indonesia. Oleh karena itu, asupan makan pada penelitian ini disebut asupan makan DASH like diet.

Penelitian ini dilakukan pada subjek wanita karena beberapa penelitian menyebutkan bahwa wanita memiliki risiko lebih tinggi mengalami prediabetes dibandingkan pria $(7,8)$. Hal ini karena wanita lebih sensitif terhadap efek penekanan peningkatan berat badan dibanding pria sehingga risiko overweight dan obesitas lebih tinggi dialami oleh wanita (9). Selain itu, wanita lebih berisiko mengalami prediabetes karena faktor melahirkan bayi dengan berat lahir lebih dari $4 \mathrm{~kg}$ (10).

Jumlah individu dengan prediabetes di Indonesia semakin tinggi tetapi manajemen untuk pasien prediabetes dengan hipertensi belum banyak dikaji terutama dari aspek asupan makan. Selain itu, kurangnya pedoman dan skrining prediabetes serta kesadaran masyarakat untuk memeriksa kadar glukosa darah membuat kondisi prediabetes tidak diketahui dan tidak diamati (7). Jika kondisi prediabetes dengan hipertensi dapat diketahui sejak dini, maka peningkatan prevalensi diabetes dan penyakit kardiovaskular yang berhubungan dengan morbiditas, mortalitas, biaya, dan risiko progresivitas penyakit dapat dicegah.

\section{BAHAN DAN METODE}

Penelitian dilakukan di wilayah kerja Puskesmas Tlogosari Kulon Semarang pada bulan Januari-Maret 2014. Penelitian ini merupakan penelitian observasional dengan desain cross sectional. Subjek penelitian adalah wanita prediabetes, yang diambil secara consecutive sampling, besar subjek penelitian 117 orang. Prediabetes dibuktikan dengan kadar glukosa darah puasa (GDP) sebesar 100-125 mg/dl dan atau kadar glukosa 2 jam post prandial sebesar 140-199 mg/dl. Darah diambil dari pembuluh vena lengan subjek setelah berpuasa minimal 8 jam kemudian subjek penelitian diberi 75 g glukosa yang dilarutkan dalam $250 \mathrm{ml}$ air. Setelah 2 jam pemberian glukosa, dilakukan pengukuran kadar glukosa 2 jam post prandial. Pengukuran kadar glukosa darah puasa dan 2 jam post prandial menggunakan glukometer. Pengambilan kadar GDP dilakukan oleh analis laboratorium Puskesmas Tlogosari Kulon.

Kriteria inklusi subjek penelitian antara lain berusia 30-60 tahun, tidak menggunakan kontrasepsi oral, serta belum pernah didiagnosis DMT2 dan hipertensi oleh dokter. Kriteria eksklusi antara lain tidak mematuhi prosedur penelitian, mengkonsumsi obat-obatan atau suplemen, dan dalam keadaan hamil, menyusui, atau 6 bulan setelah melahirkan. Berdasarkan perhitungan besar sampel dengan tingkat kepercayaan 95\%; proporsi (P) prediabetes yang mengalami hipertensi di Indonesia sebesar 8,3\% (7); dan presisi (d) sebesar 5\% sehingga diperoleh besar sampel sebanyak 117 orang.

Variabel independen penelitian adalah asupan makan DASH like diet dan variabel dependen adalah risiko hipertensi sedangkan variabel luar adalah riwayat penyakit keluarga, status gizi, obesitas sentral, dan aktivitas fisik. 
Tabel 1. Perbedaan pola makan DASH diet dan DASH Like Diet

\begin{tabular}{lll}
\hline Zat gizi & DASH diet & DASH Like Diet \\
\hline Karbohidrat & $55 \%$ total energi & $<55 \%$ total energi \\
Protein & $18 \%$ total energi & $>18 \%$ total energi \\
\hline Lemak & $27 \%$ total energi & $<27 \%$ total energi \\
\hline Lemak jenuh & $6 \%$ total energi & $<6 \%$ total energi \\
Serat & $30 \mathrm{~g}$ & $>25 \mathrm{~g}$ \\
Natrium & $2300 \mathrm{mg}$ & $<2300 \mathrm{mg}$ \\
Kalium & $4700 \mathrm{mg}$ & - \\
Rasio natrium : kalium & - & $<0,49$ \\
Kalsium & $1250 \mathrm{mg}$ & $>800 \mathrm{mg}$ \\
\hline Magnesium & $500 \mathrm{mg}$ & $>270 \mathrm{mg}$ \\
\hline
\end{tabular}

Pada penelitian ini, asupan makan menggunakan pedoman DASH diet tetapi terdapat beberapa zat gizi yang anjuran konsumsinya menggunakan AKG seperti asupan makan DASH like diet pada Tabel 1. Data asupan makan subjek selama 3 bulan terakhir diperoleh melalui wawancara menggunakan Food Frequency Questionnaire (FFQ). Pada penelitian ini, digunakan skor DASH target karena mencapai asupan gizi merupakan tujuan dari rekomendasi DASH diet. Setiap asupan zat gizi yang memenuhi target DASH like diet diberi skor 1; pada target pertengahan diberi skor 0,5 ; dan tidak memenuhi target diberi skor 0 (Tabel 2). Subjek penelitian dikategorikan memenuhi asupan makan DASH like diet jika skor total lebih dari atau sama dengan 4,5. Skor total asupan DASH like diet didapatkan dari penjumlahan zat gizi karbohidrat, protein, lemak total, lemak jenuh, serat, natrium $(\mathrm{Na})$, rasio natrium kalium (Na:K), kalsium (Ca), dan magnesium $(\mathrm{Mg})$. Pedoman asupan makan menggunakan DASH diet dan AKG Indonesia tahun 2004 (11,12).
Risiko hipertensi adalah hasil pengukuran tekanan darah lebih dari 120/80 mmHg. Tekanan darah diukur 2 kali oleh perawat pada lengan subjek dengan posisi duduk setelah istirahat 10 menit menggunakan sphygmomanometer air raksa. Risiko hipertensi ditentukan berdasarkan hasil rerata kedua pengukuran tekanan darah, berisiko hipertensi jika tekanan darah lebih dari atau sama dengan 120/80 mmHg (13).

Status gizi diketahui berdasarkan nilai indeks massa tubuh (IMT) dan dikategorikan obesitas jika IMT lebih dari atau sama dengan $25 \mathrm{~kg} / \mathrm{m}^{2}$ (14). Pengukuran berat badan menggunakan timbangan digital dan tinggi badan dengan microtoise. Sementara itu, obesitas sentral diketahui berdasarkan hasil pengukuran lingkar pinggang (LP) jika lebih dari $80 \mathrm{~cm}$ (14). Pengukuran LP dilakukan dengan menggunakan pita ukur midline, dilakukan secara horizontal dan melingkar pada kulit daerah abdomen tanpa alas kain dengan patokan titik tengah antara kosta terbawah dengan krista iliaka pada posisi berdiri. Aktivitas fisik adalah aktivitas yang dilakukan oleh responden sehari-hari yang diukur menggunakan kuesioner International Physical Activity Questionnaire (IPAQ) dengan kriteria aktivitas ringan (3,3 METs), sedang (4,0 METs), dan berat (8,0 METs) kemudian perhitungan tiap aktivitas fisik dengan cara mengkalikan faktor aktivitas dengan lamanya kegiatan yang dilakukan dalam menit dan banyaknya kegiatan dilakukan dalam seminggu. Selanjutnya, hasil dari perhitungan tersebut dijumlahkan dan dikelompokkan menjadi aktivitas rendah jika aktivitas fisik kurang dari 3000 MET-menit/minggu dan aktivitas tinggi jika aktivitas fisik lebih dari 3000 MET-menit/minggu (15).

Tabel 2. Kriteria asupan makan DASH Like Diet

\begin{tabular}{llll}
\hline \multicolumn{1}{c}{ Komponen zat gizi } & $\begin{array}{l}\text { DASH target } \\
\text { (Skor } 1=\text { Baik) }\end{array}$ & $\begin{array}{l}\text { Target pertengahan } \\
\text { (Skor 0,5 }=\text { Sedang) }\end{array}$ & $\begin{array}{l}\text { Tidak memenuhi target } \\
\text { (Skor 0 = Buruk) }\end{array}$ \\
\hline Karbohidrat (\% total energi) & $<55$ & $\geq 55$ s.d $<65$ & $\geq 65$ \\
Protein (\% total energi) & $>18$ & $>16,50$ s.d $\leq 18$ & $<16,50$ \\
Lemak (\% total energi) & $<27$ & $\geq 27$ s.d $<32$ & $\geq 32$ \\
Lemak jenuh (\% total energi) & $<6$ & $\geq 6 \%$ s.d $<11$ & $\geq 11$ \\
Serat $(\mathrm{g})$ & $>25$ & $>16,26$ s.d $\leq 25$ & $\leq 16,26$ \\
Natrium $(\mathrm{mg})$ & $<2.300$ & $\geq 2.300$ s.d $<2.684$ & $\geq 2.684$ \\
Rasio Na $: \mathrm{K}$ & $<0,49$ & $\geq 0,49$ s.d $<0,84$ & $\geq 0,84$ \\
Kalsium $(\mathrm{mg})$ & $>800$ & $>544,62$ s.d $\leq 800$ & $\leq 544,62$ \\
Magnesium $(\mathrm{mg})$ & $>270$ & $>179,30$ s.d $\leq 270$ & $\leq 179,30$ \\
\hline
\end{tabular}

Sumber: US HHS, 2006; Depkes RI, 2004; Na = Natrium; K = Kalium 
Uji Chi-Square digunakan untuk mengetahui hubungan antara asupan makan DASH like diet dengan hipertensi. Sementara itu, uji regresi logistik digunakan untuk mengetahui faktor yang paling dominan berhubungan dengan risiko hipertensi. Penelitian ini telah mendapat surat kelaikan etik (ethical approval) dari Universitas Gadjah Mada dengan nomor surat KE/ FK/58/EC.

\section{HASIL}

Sebanyak 198 wanita bersedia diperiksa kadar glukosa darah puasa dan glukosa darah 2 jam post prandial kemudian diperoleh 117 wanita yang sesuai kriteria inklusi dan menjadi subjek penelitian. Berdasarkan Tabel 3 diketahui bahwa sebagian besar subjek penelitian (48,72\%) berusia 51-60 tahun. Prevalensi prediabetes terus meningkat sejalan dengan peningkatan usia (8). Sebagian besar subjek penelitian tamat SMA $(52,99 \%)$ dan merupakan ibu rumah tangga $(66,67 \%)$.

Tabel 4 menunjukkan bahwa 60,68\% subjek penelitian memiliki riwayat penyakit keluarga diabetes mellitus (DM) dan atau hipertensi. Hipertensi dapat terjadi pada seseorang yang memiliki riwayat hipertensi, penyakit kardiovaskular, hiperlipidemia, atau DM pada keluarganya (16). Berdasarkan kategori status gizi (14), sebanyak 71,79\% subjek memiliki IMT lebih dari atau sama dengan $25 \mathrm{~kg} /$ $\mathrm{m}^{2}$ yang tergolong obesitas. Wanita lebih sensitif pada efek penekanan peningkatan berat badan dibanding pria sehingga risiko overweight dan obesitas lebih tinggi dialami oleh wanita (9). Risiko kelainan kardiovaskular pada wanita prediabetes lebih tinggi dibanding pria prediabetes dengan rasio hazard 2,07 pada wanita prediabetes dan 1,86 pada pria prediabetes (17).

Sebagian besar subjek penelitian belum pernah melakukan pemeriksaan kadar glukosa darah puasa dan 2 jam post prandial. Pada penelitian ini, sebanyak $63,25 \%$ subjek penelitian tergolong glukosa darah puasa terganggu (GDPT); 24,79\% tergolong GDPT dan toleransi glukosa terganggu (TGT); serta 11,97\% tergolong TGT. Selain itu, sebanyak 63,25\% subjek penelitian tidak memiliki kebiasaan olahraga dan $90,60 \%$ tergolong memiliki aktivitas rendah. Sebagian
Tabel 3. Karakteristik subjek penelitian

\begin{tabular}{lcc}
\hline \multicolumn{1}{c}{ Variabel } & $\mathbf{n = 1 1 7}$ & $\mathbf{\%}$ \\
\hline Usia (tahun) & & \\
$30-40$ & 6 & 5,13 \\
$41-50$ & 54 & 46,15 \\
$51-60$ & 57 & 48,72 \\
Tingkat pendidikan & & \\
Tidak sekolah & 3 & 2,56 \\
SD & 15 & 12,82 \\
SMP & 25 & 21,37 \\
SMA & 62 & 52,99 \\
Perguruan tinggi & 12 & 10,26 \\
Pekerjaan & & \\
Ibu rumah tangga & 78 & 66,67 \\
PNS & 2 & 1,71 \\
Swasta & 8 & 6,84 \\
Wiraswasta & 25 & 21,37 \\
Pensiunan & 4 & 3,42 \\
\hline
\end{tabular}

Tabel 4. Profil subjek penelitian terkait faktor risiko hipertensi

\begin{tabular}{lcc}
\hline \multicolumn{1}{c}{ Variabel } & $\mathbf{n}=\mathbf{1 1 7}$ & $\mathbf{\%}$ \\
\hline Riwayat penyakit keluarga & & \\
$\quad$ Ada & 71 & 60,68 \\
$\quad$ Tidak & 46 & 39,32 \\
Status gizi & & \\
$\quad$ Obesitas (IMT $\left.\geq 25 \mathrm{~kg} / \mathrm{m}^{2}\right)$ & 84 & 71,79 \\
$\quad$ Normal (IMT $\left.<25 \mathrm{~kg} / \mathrm{m}^{2}\right)$ & 33 & 28,21 \\
Obesitas sentral & & \\
$\quad$ Obesitas sentral $(\mathrm{LP} \geq 80 \mathrm{~cm})$ & 85 & 72,65 \\
$\quad$ Normal $(\mathrm{LP}<80 \mathrm{~cm})$ & 32 & 27,35 \\
Kebiasaan olah raga & & \\
$\quad$ Ya & 43 & 36,75 \\
$\quad$ Tidak & 74 & 63,25 \\
Aktivitas fisik & & \\
$\quad$ Tinggi $(\geq 3000 \mathrm{MET}-\mathrm{mnt} / \mathrm{mg})$ & 11 & 9,40 \\
$\quad$ Rendah $(<3000 \mathrm{MET}-\mathrm{mnt} / \mathrm{mg})$ & 106 & 90,60 \\
Kategori prediabetes & & \\
$\quad$ GDPT & 74 & 63,25 \\
$\quad$ TGT & 14 & 11,97 \\
$\quad$ GDPT dan TGT & 29 & 24,79 \\
Risiko hipertensi & & \\
Berisiko $(\mathrm{TD} \geq 120 / 80 \mathrm{mmHg})$ & 65 & 55,56 \\
$\quad$ Tidak (TD $<120 / 80 \mathrm{mmHg})$ & 52 & 44,44 \\
\hline
\end{tabular}

IMT = indeks massa tubuh; $\mathrm{LP}=$ lingkar pinggang;

MET $=$ metabolic equivalent $;$ GDPT $=$ glukosa darah puasa terganggu;

$\mathrm{TGT}=$ toleransi glukosa terganggu; $\mathrm{TD}=$ tekanan darah 
Tabel 5. Uji bivariat variabel luar dengan risiko hipertensi

\begin{tabular}{|c|c|c|c|c|c|c|c|}
\hline \multirow[t]{2}{*}{ Variabel } & \multicolumn{2}{|c|}{$\begin{array}{c}\text { Berisiko hipertensi } \\
(n=65)\end{array}$} & \multicolumn{2}{|c|}{$\begin{array}{c}\text { Tidak berisiko } \\
\text { hipertensi }(\mathrm{n}=52)\end{array}$} & \multirow{2}{*}{$\mathbf{R P}$} & \multirow{2}{*}{$95 \%$ CI } & \multirow{2}{*}{$\mathbf{p}$} \\
\hline & $\mathbf{n}$ & $\%$ & $\mathbf{n}$ & $\%$ & & & \\
\hline \multicolumn{8}{|c|}{ Riwayat penyakit keluarga } \\
\hline Ada & 46 & 70,77 & 25 & 48,08 & 1,57 & $1,07-2,30$ & 0,012 \\
\hline Tidak & 19 & 29,23 & 27 & 51,92 & & & \\
\hline \multicolumn{8}{|l|}{ Status gizi } \\
\hline Obesitas & 54 & 83,08 & 30 & 57,69 & 1,93 & $1,16-3,21$ & 0,002 \\
\hline Normal & 11 & 16,92 & 22 & 42,31 & & & \\
\hline \multicolumn{8}{|l|}{ Obesitas sentral } \\
\hline Obesitas sentral & 53 & 81,54 & 32 & 61,54 & 1,66 & $1,03-2,68$ & 0,016 \\
\hline Normal & 12 & 18,46 & 20 & 38,46 & & & \\
\hline \multicolumn{8}{|l|}{ Aktivitas fisik } \\
\hline Rendah & 59 & 90,77 & 47 & 90,38 & 0,98 & $0,56-1,73$ & 0,943 \\
\hline Tinggi & 6 & 9,23 & 5 & 9,62 & & & \\
\hline
\end{tabular}

besar subjek penelitian prediabetes $(55,56 \%)$ tergolong berisiko hipertensi. Jumlah individu prediabetes dengan hipertensi 2-3 kali lebih tinggi dibanding individu yang sehat. Prediabetes dan prehipertensi meningkatkan jumlah kejadian kardiovaskular 2,06 kali lebih tinggi dibanding individu dengan normotensi normoglikemi (18).

Tabel 5 menunjukkan bahwa subjek penelitian dengan riwayat DM dan atau hipertensi pada keluarga, memiliki status gizi obesitas, dan tergolong obesitas sentral berisiko lebih tinggi untuk mengalami hipertensi secara berturut-turut sebesar 1,57 kali $(\mathrm{p}=0,012) ; 1,93$ kali ( $p=0,002)$; dan 1,66 kali $(p=0,016)$. Demikian juga dengan subjek penelitian yang memiliki aktivitas rendah $(90,77 \%)$ berisiko hipertensi. Namun, hasil uji bivariat menunjukkan tidak terdapat hubungan antara aktivitas fisik dengan risiko hipertensi $(p=0,943)$. Hal ini disebabkan sebagian besar subjek penelitian melakukan aktivitas fisik yang seragam dan tergolong rendah.

Berdasarkan Tabel 6, hanya 2 variabel yang secara statistik bermakna yaitu asupan lemak $(\mathrm{p}=0,027)$ dan natrium $(p=0,043)$. Subjek penelitian yang tidak berisiko hipertensi cenderung mengkonsumsi protein, serat, kalium, dan kalsium lebih tinggi dibanding yang berisiko hipertensi. Hal ini sejalan dengan National Health and Nutrition Examination Survey (NHANES) III bahwa kelompok DASH like diet mengkonsumsi asupan makan tinggi kalori, protein, karbohidrat, serat, kalium, magnesium, dan kalsium, namun rendah lemak dan lemak jenuh (19).
Rerata skor asupan makan DASH like diet pada subjek penelitian tidak berisiko hipertensi $(3,31)$ lebih tinggi dibanding yang berisiko hipertensi $(3,23)$. Rerata asupan makan DASH like diet pada subjek penelitian yang tidak berisiko maupun berisiko hipertensi belum memenuhi skor asupan makan yang sesuai DASH like $\operatorname{diet}(>4,5)$. Skor asupan makan DASH like diet terendah adalah 1 dan tertinggi adalah 5,5 dari total skor 9 . Pada Tabel 7 sebanyak 90,77\% subjek penelitian yang asupan makannya berisiko hipertensi tidak memenuhi asupan makan DASH like diet. Hanya 17,31\% subjek penelitian yang tidak berisiko hipertensi yang memenuhi asupan makan DASH like diet. Subjek penelitian yang tidak mengkonsumsi asupan makan DASH like diet lebih banyak yang berisiko hipertensi dibanding yang mengkonsumsi asupan makan DASH like diet. Terdapat hubungan antara asupan makan DASH like diet dengan risiko hipertensi pada wanita prediabetes. Namun, hasil uji bivariat antara asupan makan DASH like diet dengan risiko hipertensi menunjukkan hubungan yang tidak signifikan ( $p>0,05)$.

Berdasarkan hasil analisis bivariat didapatkan 7 variabel yang memiliki nilai $\mathrm{p}$ kurang dari 0,25 yaitu riwayat penyakit keluarga, status gizi, obesitas sentral, asupan lemak, asupan lemak jenuh, asupan natrium, dan asupan makan DASH like diet. Berdasarkan uji regresi logistik model 2 (analisis tanpa variabel obesitas sentral) pada Tabel 8 diperoleh hasil bahwa faktor-faktor yang berhubungan dengan risiko hipertensi antara lain riwayat 
Ayu Rahadiyanti, dkk: Asupan makan DASH-like diet untuk mencegah risiko hipertensi pada wanita prediabetes

Tabel 6. Uji bivariat asupan zat gizi dengan risiko hipertensi

\begin{tabular}{|c|c|c|c|c|c|c|}
\hline \multirow[t]{2}{*}{ Zat gizi } & \multicolumn{2}{|c|}{$\begin{array}{c}\text { Berisiko hipertensi } \\
(\mathrm{n}=65)\end{array}$} & \multicolumn{2}{|c|}{$\begin{array}{c}\text { Tidak berisiko } \\
\text { hipertensi }(n=52)\end{array}$} & \multirow[t]{2}{*}{$\mathrm{RP}(95 \% \mathrm{CI})$} & \multirow[t]{2}{*}{$\mathbf{p}$} \\
\hline & $\mathrm{n}$ & $\%$ & $\mathrm{n}$ & $\%$ & & \\
\hline \multicolumn{7}{|l|}{ Karbohidrat } \\
\hline Buruk & 23 & 35,38 & 20 & 38,46 & 1,00 & 0,935 \\
\hline Sedang & 23 & 35,38 & 18 & 34,62 & $0,95(0,65-1,41)$ & \\
\hline Baik & 19 & 29,23 & 14 & 26,92 & $0,93(0,62-1,39)$ & \\
\hline \multicolumn{7}{|l|}{ Protein } \\
\hline Buruk & 41 & 63,08 & 31 & 59,62 & 1,00 & 0,609 \\
\hline Sedang & 10 & 15,38 & 6 & 11,54 & $0,91(0,59-1,40)$ & \\
\hline Baik & 14 & 21,54 & 15 & 28,85 & $1,18(0,77-1,81)$ & \\
\hline \multicolumn{7}{|l|}{ Lemak } \\
\hline Buruk & 30 & 46,15 & 19 & 36,54 & 1,00 & 0,027 \\
\hline Sedang & 14 & 21,54 & 23 & 44,23 & $1,62(1,01-2,59)$ & \\
\hline Baik & 21 & 32,31 & 10 & 19,23 & $0,90(0,65-1,26)$ & \\
\hline \multicolumn{7}{|l|}{ Lemak jenuh } \\
\hline Buruk & 47 & 72,31 & 44 & 84,62 & $0,75(0,54-1,03)$ & 0,112 \\
\hline Sedang & 18 & 27,69 & 8 & 15,38 & & \\
\hline \multicolumn{7}{|l|}{ Serat } \\
\hline Rendah & 65 & 100 & 52 & 100 & - & - \\
\hline \multicolumn{7}{|l|}{ Natrium } \\
\hline Buruk & 3 & 4,62 & 0 & 0 & 1,00 & 0,043 \\
\hline Sedang & 7 & 10,77 & 1 & 1,92 & $1,14(0,88-1,48)$ & \\
\hline Baik & 55 & 84,62 & 51 & 98,08 & $1,93(1,61-2,31)$ & \\
\hline \multicolumn{7}{|l|}{ Kalium } \\
\hline Rendah & 65 & 100 & 52 & 100 & - & - \\
\hline \multicolumn{7}{|l|}{ Rasio Na:K } \\
\hline Buruk & 47 & 72,31 & 33 & 63,46 & 1,00 & 0,592 \\
\hline Sedang & 16 & 24,62 & 17 & 32,69 & $1,21(0,81-1,80)$ & \\
\hline Baik & 2 & 3,08 & 2 & 3,85 & $1,17(0,43-3,18)$ & \\
\hline \multicolumn{7}{|l|}{ Kalsium } \\
\hline Buruk & 60 & 92,31 & 45 & 86,54 & $1,37(0,69-2,73)$ & 0,307 \\
\hline Sedang & 5 & 7,69 & 7 & 13,46 & & \\
\hline \multicolumn{7}{|l|}{ Magnesium } \\
\hline Buruk & 1 & 1,54 & 1 & 1,92 & 1,00 & 0,725 \\
\hline Sedang & 23 & 35,38 & 22 & 42,31 & $0,98(0,24-4,03)$ & \\
\hline Baik & 41 & 63,08 & 29 & 55,77 & $0,85(0,21-3,46)$ & \\
\hline
\end{tabular}

Asupan gizi buruk $=$ skor 0 ; sedang $=$ skor 0,$5 ;$ baik $=$ skor 1

Tabel 7. Uji bivariat asupan makan DASH like diet dengan risiko hipertensi

\begin{tabular}{|c|c|c|c|c|c|c|c|}
\hline \multirow[t]{2}{*}{ Variabel } & \multicolumn{2}{|c|}{$\begin{array}{c}\text { Berisiko } \\
\text { hipertensi }(n=65)\end{array}$} & \multicolumn{2}{|c|}{$\begin{array}{c}\text { Tidak berisiko } \\
\text { hipertensi }(\mathrm{n}=52)\end{array}$} & \multirow[t]{2}{*}{$\mathbf{R P}$} & \multirow[t]{2}{*}{$95 \% \mathrm{CI}$} & \multirow[t]{2}{*}{$\mathbf{p}$} \\
\hline & n & $\%$ & $\mathrm{n}$ & $\%$ & & & \\
\hline \multicolumn{8}{|l|}{ Asupan DASH like diet } \\
\hline No DASH $($ skor $<4,5)$ & 59 & 90,77 & 43 & 82,69 & 1,45 & $0,76-2,75$ & 0,194 \\
\hline DASH $($ skor $\geq 4,5)$ & 6 & 9,23 & 9 & 17,31 & & & \\
\hline
\end{tabular}


Tabel 8. Regresi logistik faktor-faktor yang berhubungan dengan risiko hipertensi

\begin{tabular}{lcccc}
\hline \multirow{2}{*}{\multicolumn{1}{c}{ Variabel }} & \multicolumn{3}{c}{ Model 1 } & \multicolumn{2}{c}{ Model 2 } \\
\cline { 2 - 5 } & OR & $\mathbf{p}$ & OR & $\mathbf{p}$ \\
\hline Riwayat penyakit keluarga & 2,39 & 0,044 & 2,35 & 0,047 \\
Obesitas & 2,51 & 0,124 & 3,16 & 0,016 \\
Obesitas sentral & 1,45 & 0,529 & - & - \\
Asupan lemak & 0,34 & 0,018 & 0,33 & 0,015 \\
Asupan lemak jenuh & 0,69 & 0,513 & 0,70 & 0,522 \\
Asupan natrium & 5,92 & 0,120 & 5,97 & 0,116 \\
Asupan makan DASH like diet & 2,11 & 0,259 & 2,05 & 0,276 \\
\hline
\end{tabular}

penyakit keluarga, obesitas, dan asupan lemak. Subjek yang memiliki riwayat DM dan atau hipertensi pada keluarga berisiko hipertensi 2,35 kali lebih tinggi dibanding subjek tanpa riwayat penyakit keluarga $(\mathrm{p}=0,047 ; 95 \%$ CI:1,01-5,49). Subjek obesitas berisiko hipertensi 3,16 kali lebih tinggi dibanding subjek dengan status gizi normal ( $p=0,016$; 95\% CI:1,24-8,02). Lebih lanjut, subjek yang mengkonsumsi lemak sedang (27-32\% total energi) berisiko hipertensi 0,33 kali lebih rendah dibandingkan subjek yang mengkonsumsi lemak tinggi ( $>32 \%$ total energi) $(\mathrm{p}=0,015$; 95\% CI:0,13-0,80).

\section{BAHASAN}

\section{Karakteristik subjek penelitian}

Sebagian besar subjek penelitian berusia 51-60 tahun. Risiko prediabetes meningkat sejalan dengan peningkatan usia (2). Penelitian ini serupa dengan penelitian yang dilakukan di China dengan hasil prevalensi prediabetes pada wanita usia 40-49 tahun sebesar 9,4\% dan prevalensi tersebut terus meningkat sejalan dengan peningkatan usia (8). Sebagian besar subjek penelitian merupakan ibu rumah tangga dengan pendidikan terakhir SMA. Berdasarkan penelitian di Oman, sebesar $54,68 \%$ subjek penelitian yang tidak bekerja mengalami prediabetes. Prevalensi prediabetes pada subjek penelitian yang tidak bekerja cenderung lebih tinggi dibanding yang bekerja (20). Lebih lanjut, pengukuran status gizi berdasarkan IMT menunjukkan sebagian besar subjek tergolong obesitas. Risiko hipertensi pada wanita obes yang berusia kurang dari 50 tahun 5,07 kali lebih tinggi dibandingkan wanita nonobes (21). Wanita lebih sensitif pada efek penekanan peningkatan berat badan dibanding pria sehingga risiko overweight dan obesitas lebih tinggi dialami oleh wanita (9).

Prediabetes tidak menunjukkan gejala namun prediabetes merupakan faktor risiko utama menuju DMT2 dan penyakit jantung. Prediabetes memiliki risiko 5-15 kali lebih tinggi mengalami DM dibanding individu dengan kadar glukosa normal (20). Pada penelitian ini, sebagian besar subjek tergolong GDPT, disusul oleh GDPT dan TGT, serta TGT menempati persentase terkecil. Hasil ini menyerupai penelitian yang dilakukan pada populasi Framingham yaitu sebanyak 20\% subjek penelitian mengalami GDPT, 6\% GDPT dan TGT, serta 5\% TGT. Keadaan prediabetes dapat berkembang menjadi diabetes dengan prevalensi kejadian diabetes 1,3\% pada orang sehat; 4,3\% pada TGT; $9,2 \%$ pada GDPT; dan 25,5\% pada GDPT dan TGT (22). Pada penelitian ini, GDPT menempati persentase terbesar dibanding kategori prediabetes lain. Kadar GDP lebih dari $100 \mathrm{mg} / \mathrm{dl}$ diprediksi dapat meningkatkan risiko diabetes, penyakit kardiovaskular pada wanita, dan kematian (23). Peningkatan glikemia berdampak pada peningkatan prevalensi prediabetes. Pada beberapa populasi, TGT tidak meningkat walaupun insiden diabetes meningkat. Hal ini disebabkan peningkatan obesitas lebih berdampak pada peningkatan kadar GDP yang menyebabkan GDPT dibanding pada peningkatan kadar glukosa 2 jam post prandial (24).

Sebagian besar subjek penelitian prediabetes berisiko hipertensi. Jumlah individu prediabetes dengan hipertensi 2-3 kali lebih tinggi dibanding individu yang sehat (25). Penelitian yang dilakukan (7) mendapatkan hasil bahwa 50,6\% prediabetes tergolong hipertensi. Hasil Riskesdas tahun 2007 menunjukkan bahwa prevalensi hipertensi pada prediabetes sebesar $15,1 \%$ sedangkan pada non-hipertensi hanya sebesar 8,4\% (4). Penelitian di China menunjukkan hasil $78,8 \%$ prediabetes mengalami prehipertensi dan hipertensi. Prediabetes dan prehipertensi meningkatkan jumlah kejadian kardiovaskular 2,06 kali lebih tinggi dibanding individu dengan normotensi normoglikemi (18).

\section{Hubungan variabel luar dengan risiko hipertensi}

Sebagian besar subjek penelitian ini memiliki riwayat DM dan atau hipertensi. Analisis multivariat 
menunjukkan bahwa subjek penelitian dengan riwayat DM dan atau hipertensi pada keluarga memiliki risiko hipertensi 2,35 kali lebih tinggi dibanding tanpa riwayat penyakit keluarga. Penelitian di Afganistan menyebutkan bahwa individu yang memiliki riwayat keluarga DM memiliki risiko hipertensi 2,2 kali lebih tinggi dibanding tanpa riwayat diabetes (26). Risiko hipertensi pada seseorang yang kedua orangtuanya hipertensi 4,8 kali lebih tinggi dibanding tanpa riwayat hipertensi (27).

Subjek penelitian berisiko hipertensi yang memiliki IMT lebih dari atau sama dengan $25 \mathrm{~kg} / \mathrm{m}^{2}$ (obesitas) lebih banyak dibanding individu dengan IMT normal. Prevalensi hipertensi pada obesitas lebih tinggi dibanding seseorang dengan berat badan normal (6). Hasil analisis multivariat menunjukkan variabel obesitas memiliki nilai odd ratio (OR) tertinggi dibanding variabel lainnya. Hal ini disebabkan IMT merupakan prediktor terkuat kejadian hipertensi. Nilai IMT lebih dari atau sama dengan 25 $\mathrm{kg} / \mathrm{m}^{2}$ memiliki attributable risk $40 \%$ dibanding IMT kurang dari $25 \mathrm{~kg} / \mathrm{m}^{2}$ (1). Peningkatan berat badan merupakan faktor risiko utama kardiovaskular yang sangat berhubungan dengan gangguan regulasi glukosa dan peningkatan tekanan darah (18). Subjek dengan status gizi obesitas memiliki risiko 3,16 kali lebih tinggi mengalami hipertensi dibanding subjek dengan status gizi normal. Demikian juga penelitian di Korea yang menunjukkan hasil bahwa subjek dengan IMT $25-29,9 \mathrm{~kg} / \mathrm{m}^{2}$ berisiko hipertensi sistolik 3,67 kali lebih tinggi dibanding subjek penelitian dengan IMT normal (28). Penelitian sebelumnya juga menyebutkan bahwa peningkatan berat badan $10 \%$ diprediksi dapat meningkatkan tekanan darah $7 \mathrm{mmHg}$ (6).

Selain itu, diketahui bahwa subjek pada penelitian ini yang berisiko hipertensi banyak yang mengalami obesitas sentral. Obesitas sentral berhubungan dengan resistensi insulin yang dapat menyebabkan DMT2 dan berbagai faktor penyakit kardiovaskular (25). Hasil analisis menunjukkan bahwa subjek dengan obesitas sentral berisiko 1,66 lebih tinggi mengalami hipertensi dibanding individu yang normal. Berdasarkan penelitian di Afganistan, risiko hipertensi pada obesitas sentral 1,67 kali lebih tinggi dibanding individu yang normal (26).

Lebih lanjut, sebagian besar subjek yang berisiko hipertensi memiliki aktivitas tergolong rendah. Aktivitas tingkat rendah banyak dilakukan oleh ibu rumah tangga yang anaknya telah beranjak dewasa sehingga sebagian pekerjaan rumah dibantu oleh anak. Aktivitas sehari-hari ibu rumah tangga yaitu melakukan pekerjaan rumah seperti membersihkan rumah, mencuci, dan memasak. Setelah kegiatan rumah selesai, sebagian besar ibu melakukan aktivitas sedenter seperti menonton TV, berbaring, tidur, dan duduk. Sebanyak 36,75\% subjek melakukan olahraga dengan frekuensi 1 kali/minggu. Olahraga yang sering dilakukan antara lain senam, bersepeda, dan jogging.

Hasil uji bivariat menunjukkan tidak terdapat hubungan antara aktivitas fisik dengan hipertensi. Hal ini disebabkan sebagian besar subjek melakukan aktivitas fisik yang seragam dan tergolong rendah. Berbeda dengan penelitian di China bahwa risiko prediabetes pada orang yang melakukan aktivitas rendah 1,11 kali lebih tinggi dibanding yang melakukan aktivitas fisik secara teratur (8). Selain itu, aktivitas fisik yang rendah dapat meningkatkan kejadian hipertensi 30 - 50\% dibanding aktivitas fisik yang teratur. Peningkatan aktivitas fisik dari rendah menuju sedang dari 30 menit menjadi 45 menit setiap hari merupakan strategi primer untuk mencegah hipertensi (6).

\section{Hubungan asupan makan DASH like diet dengan risiko hipertensi}

Prinsip DASH diet adalah pola makan gizi seimbang yang tinggi serealia utuh, sayur dan buah; protein rendah lemak dalam jumlah sedang; serta lemak, gula, dan natrium dalam jumlah sedikit (29). Pola makan DASH diet mengandung komponen zat gizi yang mampu menurunkan tekanan darah seperti protein, serat, dan mineral (K, Ca, dan Mg) (11). Rerata skor asupan DASH like diet pada subjek penelitian yang berisiko hipertensi lebih rendah dibandingkan yang tidak berisiko hipertensi. Nilai ini tergolong rendah untuk memenuhi target asupan makan DASH like diet dengan skor lebih dari 4,5. Tidak ada seorang pun subjek penelitian yang memiliki skor maksimal DASH like diet yaitu 9. Hal ini dikarenakan sulitnya memenuhi asupan makan yang sesuai dengan DASH target. Sejalan dengan penelitian di Brazil yaitu rerata skor DASH diet sebesar 4,36 sehingga hanya 50\% pasien diabetes yang memenuhi asupan makan sesuai dengan rekomendasi DASH diet (30). 
Subjek penelitian yang tidak mengkonsumsi asupan makan DASH like diet lebih banyak yang berisiko hipertensi dibanding yang mengkonsumsi asupan makan DASH like diet. Namun, hasil uji bivariat antara asupan makan DASH like diet dengan hipertensi menunjukkan hubungan yang tidak bermakna $(\mathrm{p}>0,05)$. Penelitian yang serupa menunjukkan hasil tidak adanya perbedaan skor DASH target pada individu DM dan hipertensi, individu DM tanpa hipertensi, dan individu sehat (29). Demikian juga dengan hasil penelitian di China bahwa hasil skor DASH diet berhubungan dengan perubahan tekanan diastolik, tetapi secara statistik tidak bermakna $(\mathrm{p}=0,053)(31)$. Penelitian lain menyebutkan bahwa hanya $19 \%$ subjek hipertensi yang memenuhi asupan DASH diet (32).

Pada penelitian ini, rerata asupan makan DASH like diet pada subjek penelitian yang tidak berisiko hipertensi lebih tinggi dibanding yang berisiko hipertensi. Hal ini sejalan dengan penelitian di Amerika yang menyatakan bahwa subjek penelitian hipertensi memiliki skor DASH diet $(2,92)$ lebih rendah dibanding normotensi $(3,12)$ atau prehipertensi $(3,03)(22)$. Sejak publikasi hasil penelitian DASH diet tahun 1997, pola DASH diet banyak direkomendasikan untuk mencegah dan mengobati hipertensi. Namun, aplikasi praktisnya masih dipertanyakan. Hanya beberapa studi observasional yang mengkaji tentang kepatuhan DASH diet. Sebuah penelitian menyebutkan bahwa skor DASH memiliki hubungan terbalik dengan tekanan darah diastolik, tetapi tidak terdapat hubungan dengan tekanan darah sistolik (33). Penelitian yang dilakukan pada wanita di Amerika mendapatkan hasil bahwa wanita yang memiliki skor DASH diet lebih tinggi memiliki tekanan darah sistolik dan diastolik lebih rendah dibanding kelompok kontrol (34).

DASH diet yang dimodifikasi di Indonesia terdiri dari $2-5,5$ porsi nasi; $3-4$ porsi sayur; $5-6$ porsi buah; $2-3$ porsi ikan; $4-5$ porsi tempe atau tahu; 1 porsi susu; dan 1 kapsul suplemen antioksidan (vitamin A, C, E, Se, dan Zn) setiap hari. DASH diet modifikasi ini dapat menurunkan tekanan sistolik sebesar 9,2 $\mathrm{mmHg}$ dan diastolik 7,6 mmHg setelah 2 bulan intervensi. Hal ini menunjukkan bahwa DASH diet yang dimodifikasi di Indonesia dapat menurunkan tekanan darah pada orang dewasa (35). Namun, penerapan DASH diet yang dimodifikasi di Indonesia masih belum dapat diterapkan secara luas oleh masyarakat. Hal ini disebabkan konsumsi buah dan susu masyarakat Indonesia masih tergolong rendah. Selain itu, terdapat anjuran konsumsi suplemen antioksidan setiap hari. Berdasarkan studi, suplemen K, $\mathrm{Ca}$, dan $\mathrm{Mg}$ tidak direkomendasikan untuk mencegah hipertensi (6). Oleh karena itu, perlu dilakukan edukasi dan konseling mengenai asupan makan DASH like diet pada masyarakat secara luas.

Pola makan DASH diet dapat menurunkan tekanan sistolik dan diastolik pada hipertensi maupun normotensi $(6,29)$. Penurunan tekanan darah pada individu dengan tekanan darah tinggi yang mengkonsumsi DASH diet lebih baik dibanding individu yang memiliki tekanan darah optimal (36). Hal inilah yang kemungkinan menjelaskan alasan hubungan asupan makan DASH like diet dengan risiko hipertensi pada penelitian ini tidak signifikan. Namun, karena tingginya risiko hipertensi pada prediabetes, pola makan DASH like diet dapat dikonsumsi untuk mengontrol dan mencegah peningkatan tekanan darah.

Berdasarkan uji regresi, faktor-faktor yang berhubungan dengan risiko hipertensi antara lain riwayat penyakit keluarga $(\mathrm{OR}=2,35)$; obesitas $(\mathrm{OR}=3,16)$; dan asupan lemak $(\mathrm{OR}=0,33)$. Risiko hipertensi pada subjek penelitian yang mengkonsumsi lemak sedang 0,33 kali lebih rendah dibanding subjek penelitian yang mengkonsumsi lemak tinggi. Diet rendah lemak atau diet dengan rasio perbandingan lemak tak jenuh dengan lemak jenuh yang tinggi menunjukkan penurunan tekanan sistolik dan diastolik, dengan penurunan tekanan darah yang lebih tinggi pada individu dengan hipertensi dibanding normotensi (9).

Adapun keterbatasan pada penelitian ini yaitu asupan Na tidak ditanyakan secara rinci terutama asupan yang berasal dari makanan olahan dan penggunaan garam meja sehingga jumlah asupan Na kurang dapat menggambarkan asupan Na secara tepat. Validasi asupan Na dapat dilakukan dengan pemeriksaan urin 24 jam tetapi hal ini sulit dilakukan karena keterbatasan waktu, dana, dan tenaga. Metode FFQ digunakan karena lebih dapat menggambarkan asupan zat gizi tertentu dan keragaman asupan makan subjek penelitian. Dibandingkan metode penilaian asupan makan yang lain, metode FFQ lebih 
akurat, mudah, dan sering digunakan untuk mengetahui hubungan kebiasaan makan dengan penyakit (37).

\section{SIMPULAN DAN SARAN}

Asupan makan yang tidak sesuai DASH like diet dapat meningkatkan risiko hipertensi tetapi secara statistik tidak signifikan. Wanita prediabetes yang obesitas perlu melakukan penurunan berat badan agar tekanan darah terkontrol. Hal ini dapat dilakukan dengan edukasi kepada subjek untuk meningkatkan aktivitas fisik seperti olahraga 3x/minggu selama 30 menit dan mengurangi aktivitas sedenter seperti menonton TV, berbaring, dan duduk. Selain itu, tenaga gizi juga perlu memberikan edukasi mengenai asupan makan DASH like diet untuk mencegah peningkatan tekanan darah dan gangguan kardiovaskular pada prediabetes. Hal ini dapat dilakukan dengan pemberian konseling kepada pasien yang berisiko hipertensi. Penelitian serupa dengan metode penelitian cohort diperlukan untuk melihat hubungan asupan makan DASH like diet dengan risiko hipertensi.

\section{RUJUKAN}

1. Forman JP, Stampfer MJ, Curhan GC. Diet and lifestyle risk factors associated with incident hypertension in women. JAMA 2009;302(4):401-11.

2. Singh K, Ansari M, Galipeau J, Garritty C, Keely E, Malcolm J, Skidmore B, Sorisky A. An evidence map of systematic reviews to inform interventions in prediabetes. Can J Diabetes 2012;36(5):281-91.

3. International Diabetes Federation (IDF). Diabetes atlas: prevalence. [series online] 2011 [cited 2013 Feb 27]. Available from: URL: http://www.idf.org/diabetesatlas/5e/ the-global-burden

4. Badan Penelitian dan Pengembangan Kesehatan Departemen Kesehatan (Balitbangkes). Riset Kesehatan Dasar (RISKESDAS) 2007. Jakarta: Departemen Kesehatan Republik Indonesia; 2008.

5. Agarwal SK. Prediabetes in hypertensive patients: a common and dangerous comorbidity. Disease 2013;3(8):22-5.

6. Krummel DA. Chapter 36: Medical nutrition therapy in hipertension. In: Mahan LK, Stump ES. Krause's food, nutrition, and diet theraphy $11^{\text {th }}$ edition. Canada: Saunders Elsevier; 2004.

7. Soewondo P, Pramono LA. Prevalence, characteristics, and predictors of pre-diabetes in Indonesia. Med J Indones 2009;20(4):283-94.
8. Xu W, Xu Z, Jia J, Xie Y, Wang HX, Qi X. Detection of prediabetes and undiagnosed type 2 diabetes: a large population-based study. Can J Diabetes 2012;36(3):108-13.

9. Williams B. Epidemiology and pathogenesis of hypertension in people with diabetes mellitus. In: Hypertension in diabetes. London: Taylor \& Francis Group; 2004.

10. Chiasson JL, Bernard S. Reducing cardiovascular risk factors in patients with prediabetes. Diabetes Manage 2011;1(4):423-38.

11. US Department of Health and Human Services (US HHS). Your guide to lowering your blood pressure with DASH. USA: NIH Publication; 2006.

12. Departemen Kesehatan Republik Indonesia (Depkes RI). Angka Kecukupan Gizi (AKG) 2004. [series online] 2004 [cited 2013 Feb 27]. Available from: URL: http://gizi. depkes.go.id/download/AKG2004.pdf

13. US Department of Health and Human Services (US HHS). National high blood pressure education program the seventh report of the joint national committee on prevention, detection, evaluation, and treatment of high blood pressure. USA: NIH Publication; 2003.

14. WHO expert consultation. Appropriate body-mass index for Asian populations and its implications for policy and intervention strategies. The Lancet 2004;363:157-63.

15. International Physical Activity Questionnaire (IPAQ). Guidelines for data processing and analysis of the IPAQ. [series online] 2005 [cited 2013 Apr 11]. Available from: URL: http://www.ipaq.ki.se/scoring.pdf

16. Yogiantoro M. Hipertensi esensial. Dalam: Buku ajar ilmu penyakit dalam jilid II edisi V. Jakarta: Interna Publishing; 2009.

17. Eliana F, Suwondo P, Makmun LH, Harbuwono DS. ADMA as a marker of endothelial dysfunction in prediabetic women. Acta Med Indones-Indones J Intern Med 2011;43(2):92-8.

18. Wu J, Yan WH, Qiu L1, Chen XQ, Guo XZ, Wu W, Xia LY, Qin XZ, Liu YH, Ding HT, Han SM, Xu CL, Zhu GJ. High Prevalence of coexisting prehypertension and prediabetes among healthy adults in Northern and Northeastern China. BMC Public Health 2011;11:794-802.

19. Parikh A, Lipsitz SR, Natarajan S. Association between a DASH-like diet and mortality in adults with hypertension: findings from a population-based follow-up study. Am J Hypertens 2009;22(4):409-16.

20. Al-Shafaee MA, Bhargava K, Al-Farsi YM, Mcilvenny S, Al-Mandhari A, Al-Adawi S, Al-Maniri A. Prevalence of pre-diabetes and associated risk factors in an adult Omani population. Int J Diabetes Dev Ctries 2011;31:166.

21. Cohen L, Curhan GC, Forman JP. Influence of age on the association between lifestyle factors and risk of hypertension. J Am Soc Hypertens 2012;6(4):284-90. 
22. Bloomgarden ZT. Approaches to treatment of pre-diabetes and obesity and promising new approaches to type 2 diabetes. Diab Care 2008;31(7):1461-6.

23. Levitzky YS, Pencina MJ, D’Agostino RB, Meigs JB, Murabito JM, Vasan RS, Fox CS. Impact of impaired fasting glucose on cardiovascular disease. J Am Coll Cardiol 2008;51(3):264-70.

24. Tabák AG, Herder C, Rathmann W, Brunner EJ, Kivimäki M. Prediabetes: a high-risk state for diabetes development. Lancet 2012;379(9833):2279-90.

25. DeFronzo RA, Abdul-Ghani M. Assessment and treatment of cardiovascular risk in prediabetes: impaired glucose tolerance and impaired fasting glucose. Am J Cardiol 2011;108(3Supp):3B-24B.

26. Saeed KM, Rasooly MH, Brown NJ. Prevalence and predictors of adult hypertension in Kabul Afghanistan. BMC Public Health 2014;14:386.

27. Bhadoria AS, Kasar PK, Toppo NA, Bhadoria P, Pradhan S, Kabirpanthi V. Prevalence of hypertension and associated cardiovascular risk factors in Central India. J Family Community Med 2014;21(1):29-38.

28. Kim JA, Kim SM, Choi YS, Yoon D, Lee JS, Park HS, Kim HA, Lee J, Oh HJ, Choi KM. The Prevalence and risk factors associated with isolated untreated systolic hypertension in Korea: the Korean National Health and Nutrition Survey 2001. J Hum Hypertens 2007;21(2):107-13.

29. Morton S, Saydah S, Cleary SD. Consistency with the dietary approaches to stop hypertension diet among adults with diabetes. J Acad Nutr Diet 2012;112(11):1798-805.

30. de Paula TP, Steemburgo T, de Almeida JC, Dall'Alba V, Gross JL, de Azevedo MJ. The role of dietary approaches to stop hypertension (DASH) diet food groups in blood pressure in type 2 diabetes. Br J Nutr 2012;108(1):15562.

31. Lin PH, Yeh WT, Svetkey LP, Chuang SY, Chang YC, Wang C, Pan WH. Dietary intakes consistent with the dash dietary pattern reduce blood pressure increase with age and risk for stroke in a Chinese population. Asia Pac J Clin Nutr 2013;22(3):482-91.

32. Mellen PB, Gao SK, Vitolins MZ, Goff DC Jr. Deteriorating dietary habits among adults with hypertension: DASH dietary accordance, NHANES 1988-1994 and 1999-2004. Arch Intern Med 2008;168(3):308-14.

33. Mokhtari Z, Nasrollahzadeh J, Miri R, Rashidkhani B, Hosseini S. Relationship Between dietary approaches to stop hypertension score and presence or absence of coronary heart diseases in patients referring to Imam Hossein Hospital, Tehran, Iran. ARYA Atheroscler 2013;9(6):319-25.

34. Fung TT, Chiuve SE, McCullough ML, Rexrode KM, Logroscino G, Hu FB. Adherence to a DASH-style diet and riskof coronary heart disease and stroke in women. Arch Intern Med 2008;168(7):713-20.

35. Ridhwan H, Heryudarini, Setiawan B, Effendi I. An efficacy of the Indonesian modified DASH diet on reducing body weight and blood pressure. Nutr \& Diet 2012;69(Suppl 1):72-164.

36. Hinderliter AL, Babyak MA, Sherwood A, Blumenthal JA. The DASH diet and insulin sensitivity. Curr Hypertens Rep 2011;13(1):67-73.

37. Gibson RS. Principles of nutritional assessment. New York: Oxford University Press; 2005. 